\title{
Profiles of ${ }^{67} \mathrm{Cu}$ in blood, bile, urine and faeces from ${ }^{67} \mathrm{Cu}$-primed lambs: effect of ${ }^{99} \mathrm{Mo}$-labelled tetrathiomolybdate on the metabolism of ${ }^{67} \mathrm{Cu}$ after long-term storage
}

\author{
By S. R. GOONERATNE ${ }^{1 *}$, B. LAARVELD ${ }^{1}$, R. K. CHAPLIN ${ }^{2}$ \\ AND D. A. CHRISTENSEN ${ }^{1}$ \\ ${ }^{1}$ Department of Animal and Poultry Science and ${ }^{2}$ Western College of Veterinary \\ Medicine, University of Saskatchewan, Saskatoon, Saskatchewan S7N 0W0, Canada
}

(Received 24 May 1988-Accepted 4 November 1988)

1. The effectiveness of tetrathiomolybdate (TTM) in the removal of ${ }^{67} \mathrm{Cu}$ from the long-term storage compartment in liver was studied. Lambs receiving $5 \mathrm{mg} \mathrm{Cu} / \mathrm{kg}$ dry matter (DM) or $35 \mathrm{mg} \mathrm{Cu} / \mathrm{kg} \mathrm{DM}$ were primed intravenously (iv) with ${ }^{67} \mathrm{Cu}$ and challenged $10 \mathrm{~d}$ later with ${ }^{89} \mathrm{Mo}$-labelled TTM given either iv or intraduodenally (id). The profiles of ${ }^{67} \mathrm{Cu}$ and ${ }^{99} \mathrm{Mo}$ and of $\mathrm{Cu}$ and $\mathrm{Mo}$ with time were measured in blood, bile, urine and faeces.

2. The level of dietary $\mathrm{Cu}$ affected the amplitude of profiles of ${ }^{87} \mathrm{Cu}$ and $\mathrm{Cu}$ in blood, bile and urine after administration of ${ }^{99} \mathrm{Mo}$-labelled TTM. TTM administration increased liver $\mathrm{Cu}$ removal and this was most marked in sheep given TTM iv. The liver $\mathrm{Cu}$ removal from the long-term storage $\mathrm{Cu}$ compartment was low and was not affected by the route of administration of TTM. Endogenous $\mathrm{Cu}$ excretion was higher in lambs given TTM id.

3. Excretion of ${ }^{67} \mathrm{Cu}$ in bile through the transhepatocellular pathway after TTM administration appeared absent, while the transbiliary and hepatolysosomal pathways were operative. The potential reasons for this change are discussed.

4. TTM predominantly enhances the removal of $\mathrm{Cu}$ from the short-term storage compartment, but effects on the long-term storage compartment may still be of significance.

There is increasing evidence that thiomolybdates (TM) play a key role in the pathogenesis of molybdenum- and suphur-induced hypocuprosis and molybdenosis in ruminants (Dick et al. 1975; Suttle, 1980; Gooneratne, 1986; Mason, 1986). The TM not only reduce absorption of dietary copper from the gut (Mills et al. 1978), but also affect the $\mathrm{Cu}$ metabolism systemically.

Liver is the major storage organ for $\mathrm{Cu}$ (Underwood, 1977; Weber et al. 1980). Sheep accumulate excessive amounts of $\mathrm{Cu}$ in liver because their capacity to excrete excess $\mathrm{Cu}$ via bile is limited (Gooneratne et al. 1988). $\mathrm{Cu}$ is present in liver in possibly two storage compartments (Weber et al. 1983; Fig. 1): a temporary storage compartment destined for excretion in bile or incorporation into a caeruloplasmin $(\mathrm{Cp})$, and a longer-term storage compartment. The fate of $\mathrm{Cu}$ from this long-term storage compartment is obscure. However, Weber et al. (1983) described an increase in magnitude of an undefined kinetic variable $K_{20}$ (Fig. 1), representing a loss of $\mathrm{Cu}$ from the long-term storage compartment during Mo supplementation. We have previously shown that tetrathiomolybdate (TTM) efficiently removes recently stored (within $27 \mathrm{~h}$ ) tissue $\mathrm{Cu}$ (possibly of hepatic origin), by increasing its excretion via bile and endogenous secretions into the gastrointestinal tract, and via urine (Gooneratne et al. 1989). The greatest effect of TTM on bile Cu excretion occurred within $24 \mathrm{~h}$ following its administration when systemic effects were maximal. Systemic effects on $\mathrm{Cu}$ metabolism due to TTM decline after repeated injections $(100 \mathrm{mg}$ ) (Gooneratne et al. $1981 a$ ). This suggests that TTM acts primarily on the short-term liver $\mathrm{Cu}$ storage compartment and that the effects of TTM on the long-term $\mathrm{Cu}$ storage compartment may be limited. However, the latter effect has not been studied. The present investigation was

- Present address: Animal and Veterinary Sciences Group, Lincoln College, University of Canterbury, Canterbury, New Zealand. 


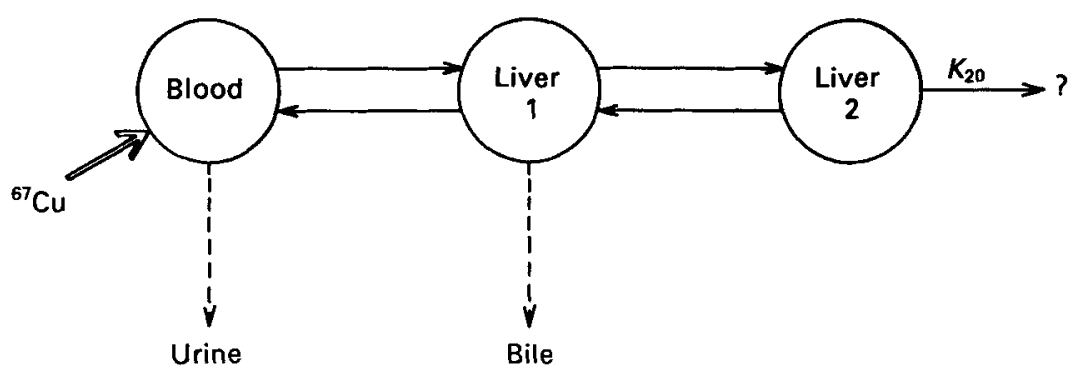

Fig. 1. Three-compartmental model describing the kinetics of intravenously administered radiolabelled copper $\left({ }^{67} \mathrm{Cu}\right)$ from Weber et al. (1983). The first compartment represents blood, and compartments 1 and 2 short- and long-term $\mathrm{Cu}$ storage compartments in the liver respectively. $K_{20}$ represents an undefined rate constant which increased with molybdenum supplementation. Compartment 0 referred to by Weber $e t$ al. (1983) was undefined, but the present study illustrates that this constitutes both bile and blood.

carried out to evaluate the fate of $\mathrm{Cu}$ in the long-term $\mathrm{Cu}$ storage compartment, and to determine the effectiveness of TTM in the removal of $\mathrm{Cu}$ from this compartment. Systemic effects of TTM and relative efficiencies of body $\mathrm{Cu}$ removal via the different excretory pathways were examined, with special emphasis on deviations in mechanisms of biliary $\mathrm{Cu}$ excretion compared with the mechanisms proposed for bile $\mathrm{Cu}$ excretion from the shortterm Cu storage compartment (Gooneratne et al. 1989).

\section{MATERIALS AND METHODS \\ Experimental animals}

Four female lambs drawn from a pool of eight cross-bred female lambs $(17-22 \mathrm{~kg})$ were used in the present study. The procedures for housing, feeding, bile duct and duodenal cannulation techniques, period of time allowed for recovery from surgery, bile flow stabilization period and sampling schedule to determine baseline values of $\mathrm{Cu}$ in plasma, bile, urine and faeces before radiotracer studies, have been reported (Gooneratne et al. 1989). The lambs received either $5.1 \mathrm{mg} \mathrm{Cu} / \mathrm{kg}$ (lamb nos. 3 and 4) or $35 \mathrm{mg} \mathrm{Cu} / \mathrm{kg}$ (lamb nos. 7 and 8 ) in the diet dry matter (DM).

\section{Radiotracer studies}

Each lamb was fitted with a Foley catheter and harness for the collection of urine and faeces respectively, before receiving the isotope. Lambs were injected intravenously (iv) with 1.5 $\mathrm{mCi}^{67} \mathrm{Cu}(0.6 \mathrm{mg} \mathrm{Cu}$ as $\mathrm{Cu}$ acetate; Oakridge National Laboratory, Oakridge, TN, USA) in $5 \mathrm{ml}$ physiological saline ( $9 \mathrm{~g}$ sodium chloride/1). One animal from each dietary group was then challenged $10 \mathrm{~d}$ later with a $5 \mathrm{ml}$ iv dose of ${ }^{99} \mathrm{Mo}$-labelled TTM $(0 \cdot 2 \mathrm{mCi}$ in $5.9 \mathrm{mg} \mathrm{Mo}$; lamb nos. 3 and 7) or with a $7.5 \mathrm{ml}$ intraduodenal (id) dose of ${ }^{99}$ Mo-labelled TTM ( $0.3 \mathrm{mCi}$ in $8.85 \mathrm{mg} \mathrm{Mo}$; lamb nos. 4 and 8$)$. The procedures for the preparation of TTM, administration and analysis of radioactivity in blood, bile, urine and faeces have been described (Gooneratne et al. 1989).

\section{Collection of blood, bile, urine and faeces}

The basic protocol for the collection of blood, bile, urine and faeces was similar to that described by Gooneratne et al (1989), except for the following. Sampling of blood, bile and urine continued at $3 \mathrm{~h}$ intervals for an additional $24 \mathrm{~h}$ for a total of $48 \mathrm{~h}$ following ${ }^{67} \mathrm{Cu}$ administration. Samples of blood, bile and urine were also collected at $3 \mathrm{~h}$ intervals for 


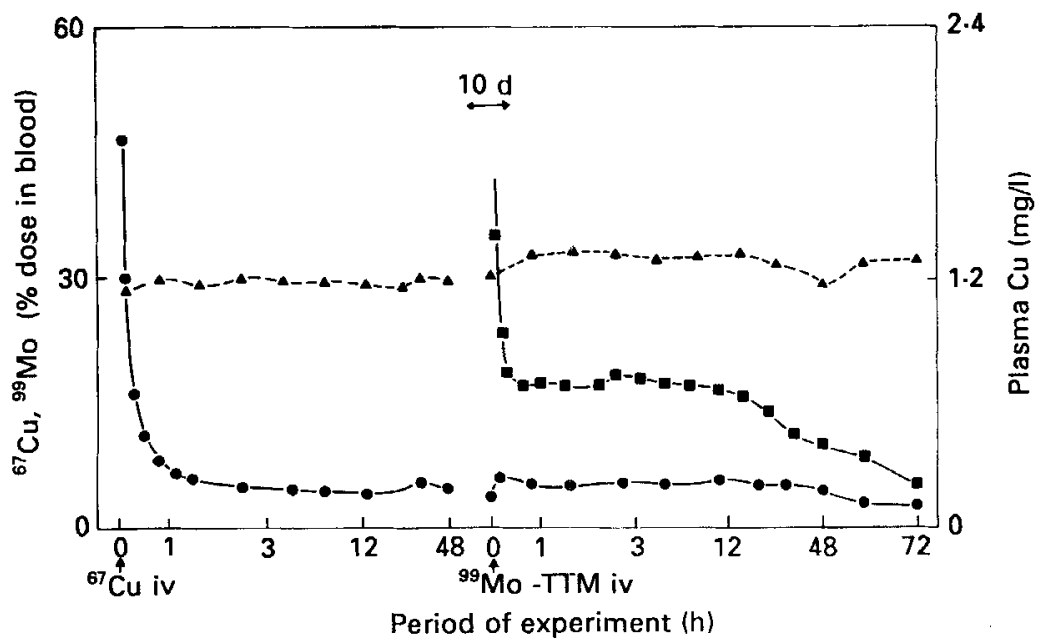

Fig. 2. Changes in ${ }^{67} \mathrm{Cu}(\mathbf{O})$ and ${ }^{99} \mathrm{Mo}(\square-\square)$ in blood, and plasma $\mathrm{Cu}(\boldsymbol{B}-\mathbf{A})$ in lamb no. 7 infused intravenously (iv) with ${ }^{67} \mathrm{Cu}(1.5 \mathrm{mCi} ; 0.6 \mathrm{mg} \mathrm{Cu})$ and challenged after $10 \mathrm{~d}$ with ${ }^{99} \mathrm{Mo}-$ labelled tetrathiomolybdate $\left({ }^{98} \mathrm{Mo}-\mathrm{TTM} ; 0.2 \mathrm{mCi}, 5.9 \mathrm{mg} \mathrm{Mo}\right)$ infused iv.

$24 \mathrm{~h}$ before TTM administration, as well as a single $24 \mathrm{~h}$ faecal sample to determine baseline ${ }^{67} \mathrm{Cu}$ and ${ }^{99} \mathrm{Mo}$ levels. The total radioactivity in blood was estimated assuming a blood volume of $7 \%$ of body-weight.

\section{$\mathrm{Cu}$ and $\mathrm{Mo}$ analyses}

$\mathrm{Cu}$ content in feed, plasma, bile, urine and faeces, and Mo in plasma and bile were determined as described previously (Gooneratne et al. 1989).

\section{RESULTS \\ Effect of dietary $\mathrm{Cu}$ on ${ }^{67} \mathrm{Cu}$ and ${ }^{99} \mathrm{Mo}$ profiles}

Before TTM administration the profiles of ${ }^{67} \mathrm{Cu}$ in blood, bile, urine and faeces were similar in lambs from both dietary groups. After TTM the peak heights and areas for ${ }^{67} \mathrm{Cu}$ and ${ }^{99}$ Mo were most marked in lambs fed on the high-Cu diet (lamb nos. 7 and 8 ).

Blood ${ }^{67} \mathrm{Cu}$ before and ${ }^{67} \mathrm{Cu}$ and ${ }^{99} \mathrm{Mo}$ after iv or id challenge with ${ }^{99} \mathrm{Mo}$-labelled TTM Clearance of ${ }^{67} \mathrm{Cu}$ from blood was rapid in all lambs. At $1 \mathrm{~h}$ after injection of ${ }^{67} \mathrm{Cu}$ about $6-8 \%$ of the injected dose remained in the circulation (Figs. 2 and 3). Blood ${ }^{67} \mathrm{Cu}$ continued to decline steadily and by $24 \mathrm{~h}$ the levels had stabilized in all animals at a level of approximately 3-5\% of the injected dose. A slight elevation of blood ${ }^{67} \mathrm{Cu}$ was observed in three lambs (nos. 3, 4 and 7) between 33 and $38 \mathrm{~h}$. Samples taken during $24 \mathrm{~h}$ before TTM administration showed that ${ }^{67} \mathrm{Cu}$ had stabilized in all animals to levels ranging from 0.8 to $1.7 \%$ of the injected dose.

Administration of TTM resulted in an immediate increase in blood ${ }^{67} \mathrm{Cu}$ levels reaching a peak of approximately $1 \cdot 1-2 \cdot 1 \%$ of the injected dose at $30 \mathrm{~min}$. Thereafter ${ }^{67} \mathrm{Cu}$ declined but slight elevations were observed at approximately 2.5 and $11 \mathrm{~h}$. A steady-state of $0.6-1 \%$ of the injected dose was reached at $65 \mathrm{~h}$. In lamb no. 7 given TTM iv (Fig. 2), four phases of ${ }^{99}$ Mo clearance were apparent: an initial rapid disappearance of ${ }^{99} \mathrm{Mo}$ reaching a plateau in $45 \mathrm{~min}$, a slight elevation at $2.5 \mathrm{~h}$, then a gradual decline over the next $9 \mathrm{~h}$, followed by a rapid decline to reach a steady equilibrium at approximately $3 \%$ of the injected dose at 


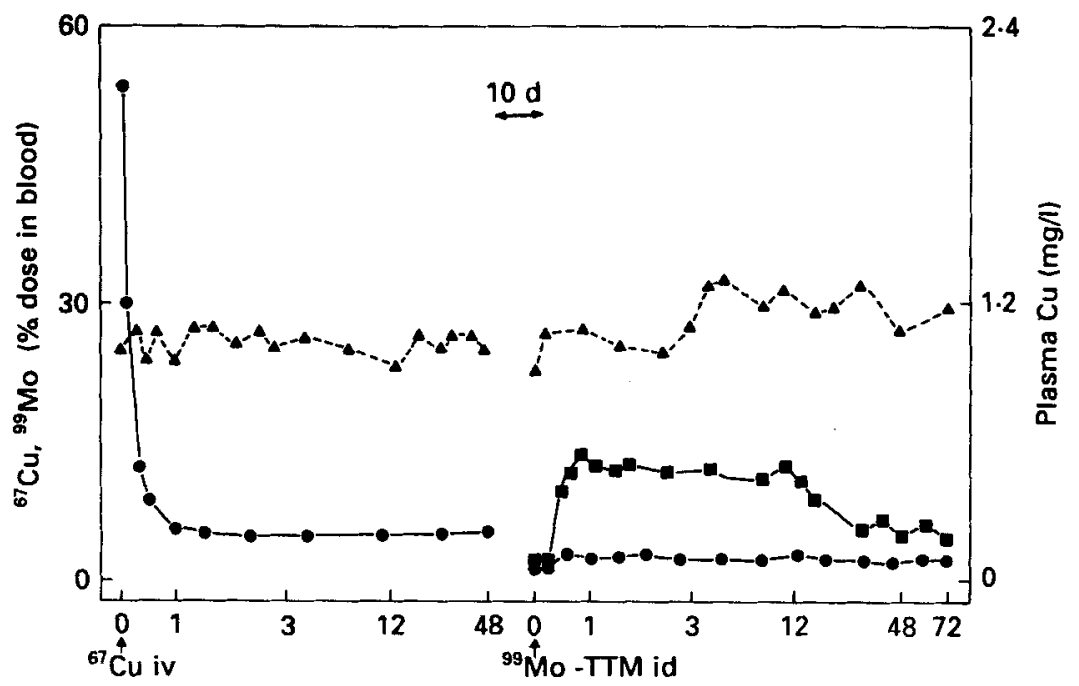

Period of experiment (h)

Fig. 3. Changes in ${ }^{67} \mathrm{Cu}\left(\mathrm{O}_{-}\right)$and ${ }^{89} \mathrm{Mo}(\mathrm{O}-\mathrm{O})$ in blood, and plasma $\mathrm{Cu}$ concentration (A- - A) in lamb no. 8 infused intravenously (iv) with ${ }^{67} \mathrm{Cu}(1.5 \mathrm{mCi} ; 0.6 \mathrm{mg} \mathrm{Cu})$ and challenged after $10 \mathrm{~d}$ with ${ }^{99} \mathrm{Mo}$-labelled tetrathiomolybdate $\left({ }^{89} \mathrm{Mo}-\mathrm{TTM} ; 0.3 \mathrm{mCi}, 8.85 \mathrm{mg} \mathrm{Mo}\right)$ infused intraduodenally (id).

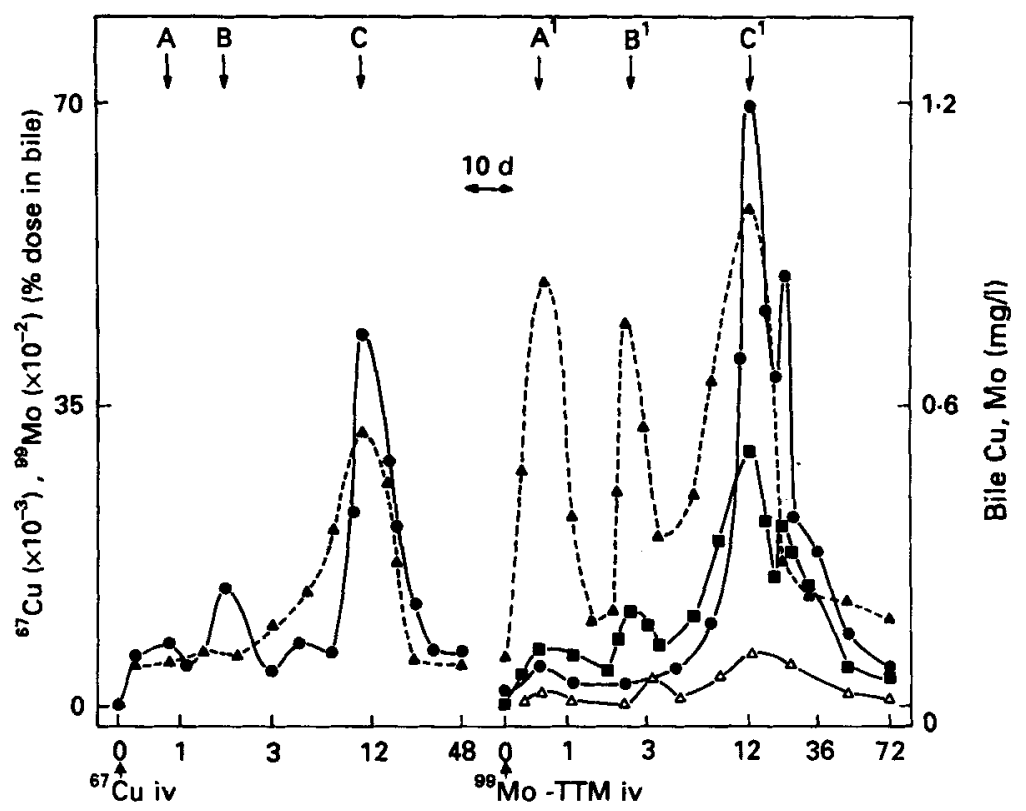

Period of experiment (h)

Fig. 4. Biliary changes in ${ }^{67} \mathrm{Cu}(\mathrm{O}-\mathrm{O}),{ }^{99} \mathrm{Mo}(\boldsymbol{\square}-\mathbf{G})$, and $\mathrm{Cu}\left(\boldsymbol{\Delta}-\mathbf{A}^{-}\right)$and $\mathrm{Mo}(\triangle-\Delta)$ concentrations in lamb no. 7 infused intravenously (iv) with ${ }^{67} \mathrm{Cu}(1.5 \mathrm{mCi} ; 0.6 \mathrm{mg} \mathrm{Cu}$ ), and challenged after $10 \mathrm{~d}$ with ${ }^{99} \mathrm{Mo}$-labelled tetrathiomolybdate $\left({ }^{99} \mathrm{Mo}-\mathrm{TTM} ; 0.2 \mathrm{mCi}, 5.9 \mathrm{mg} \mathrm{Mo}\right)$ infused iv. Peaks of ${ }^{67} \mathrm{Cu}$ excretion of increasing amplitude observed at $45 \mathrm{~min}, 2 \mathrm{~h}$ and $12 \mathrm{~h}$ after ${ }^{67} \mathrm{Cu}$ administration have been termed A, B and $\mathrm{C}$ respectively. Stable $\mathrm{Cu}$ profiles of similar pattern and frequency observed at $45 \mathrm{~min}, 2 \mathrm{~h}$ and $11.5 \mathrm{~h}$ after ${ }^{80} \mathrm{Mo}$-labelled TTM administration have been termed $\mathrm{A}^{1}, \mathrm{~B}^{1}$ and $\mathrm{C}^{1}$. Note the absence of ${ }^{67} \mathrm{Cu}$ in peak $\mathrm{B}^{1}$. 


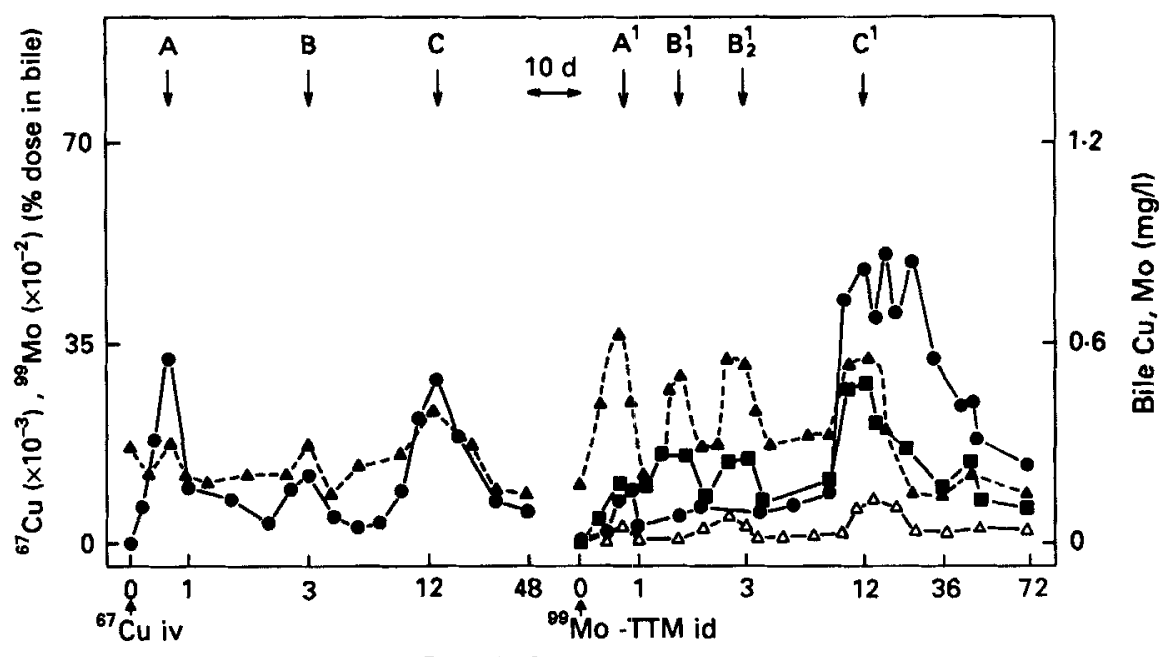

Period of experiment (h)

Fig. 5. Biliary changes in ${ }^{67} \mathrm{Cu}(--\infty),{ }^{90} \mathrm{Mo}(\square-\square)$, and $\mathrm{Cu}(\mathbf{\Delta}-\mathbf{\Delta})$ and $\mathrm{Mo}(\triangle-\triangle)$ concentrations in lamb no. 8 infused intravenously (iv) with ${ }^{67} \mathrm{Cu}(1.5 \mathrm{mCi} ; 0.6 \mathrm{mg} \mathrm{Cu}$ ), and challenged after $10 \mathrm{~d}$ with ${ }^{99} \mathrm{Mo}$-labelled tetrathiomolybdate $\left({ }^{99} \mathrm{Mo}-\mathrm{TTM} ; 0.3 \mathrm{mCi}, 8.85 \mathrm{mg} \mathrm{Mo}\right)$ infused intraduodenally (id). Peaks of ${ }^{87} \mathrm{Cu}$ excretion of increasing amplitude were observed at $30 \mathrm{~min}, 3 \mathrm{~h}$ and $12 \mathrm{~h}$ after ${ }^{67} \mathrm{Cu}$ administration, and have been termed $\mathrm{A}, \mathrm{B}$ and $\mathrm{C}$ respectively. Peaks of stable $\mathrm{Cu}$ excretion observed at $45 \mathrm{~min}, 1.75 \mathrm{~h}, 2.75 \mathrm{~h}$ and $12.5 \mathrm{~h}$ after ${ }^{90}$ Mo-labelled TTM have been termed $\mathrm{A}^{1}$, $B_{1}^{1}, B_{2}^{1}$, and $C^{1}$ respectively. Note slight elevation of ${ }^{87} \mathrm{Cu}$ at $2 \mathrm{~h}$ after TTM administration and absence of ${ }^{67} \mathrm{Cu}$ in both $\mathrm{B}_{1}^{1}$ and $\mathrm{B}_{2}^{1}$ peaks.

$72 \mathrm{~h}$. Lamb no. 3 fed on the low-Cu diet did not exhibit the elevation of ${ }^{99} \mathrm{Mo}$ at $2.5 \mathrm{~h}$. Absorption of ${ }^{99} \mathrm{Mo}$ in lambs given TTM id was rapid. The maximum concentration of ${ }^{99} \mathrm{Mo}$ in blood of $14-16 \%$ of the injected dose was observed at $45 \mathrm{~min}$. A prolonged steadystate was then observed for the following $9 \mathrm{~h}$. Following this, ${ }^{99} \mathrm{Mo}$ increased at approximately $12 \mathrm{~h}$ and then rapidly declined until $36 \mathrm{~h}$. The levels fluctuated thereafter until the end of the sampling period.

\section{Stable $\mathrm{Cu}$ concentration in plasma before and after iv or id challenge with ${ }^{90}$ Mo-labelled TTM}

Basal plasma $\mathrm{Cu}$ concentrations in all animals before the injection of ${ }^{67} \mathrm{Cu}$ varied from 0.8 to $1.2 \mathrm{mg} / \mathrm{l}$. Administration of ${ }^{67} \mathrm{Cu}$ increased stable $\mathrm{Cu}$ concentrations slightly in all but one sheep; the levels then ranged between 0.95 and $1.3 \mathrm{mg} / 1$ until TTM administration. Both iv and id TTM administration resulted in an immediate increase in plasma $\mathrm{Cu}$ concentration in all lambs and this was most marked in animals fed on the high-Cu diet. A sustained elevation of plasma $\mathrm{Cu}$ concentration was observed for $12 \mathrm{~h}$ in lamb nos. 3 and 7 (Fig. 2) given TTM iv. The plasma $\mathrm{Cu}$ concentration in lamb no. 8 after the initial elevation, declined during the next $2 \mathrm{~h}$, but again increased markedly starting at $3 \mathrm{~h}$ to peak at $7 \mathrm{~h}$. Levels declined thereafter, but a series of fluctuations was observed until the end of the sampling period.

\section{Profiles of ${ }^{87} \mathrm{Cu}$ and ${ }^{98} \mathrm{Mo}$ and excretion of $\mathrm{Cu}$ and $\mathrm{Mo}$ in bile}

Intravenous administration of ${ }^{87} \mathrm{Cu}$ immediately increased ${ }^{67} \mathrm{Cu}$ levels in bile (Figs. 4 and 5). Peaks of ${ }^{67} \mathrm{Cu}$ excretion of increasing amplitude were observed at $30 \mathrm{~min}-1 \mathrm{~h}, 2-3 \mathrm{~h}$ and at $12-13 \mathrm{~h}$ before declining to basal levels at $18-24 \mathrm{~h}$, and remained stable (Fig. 4) or 


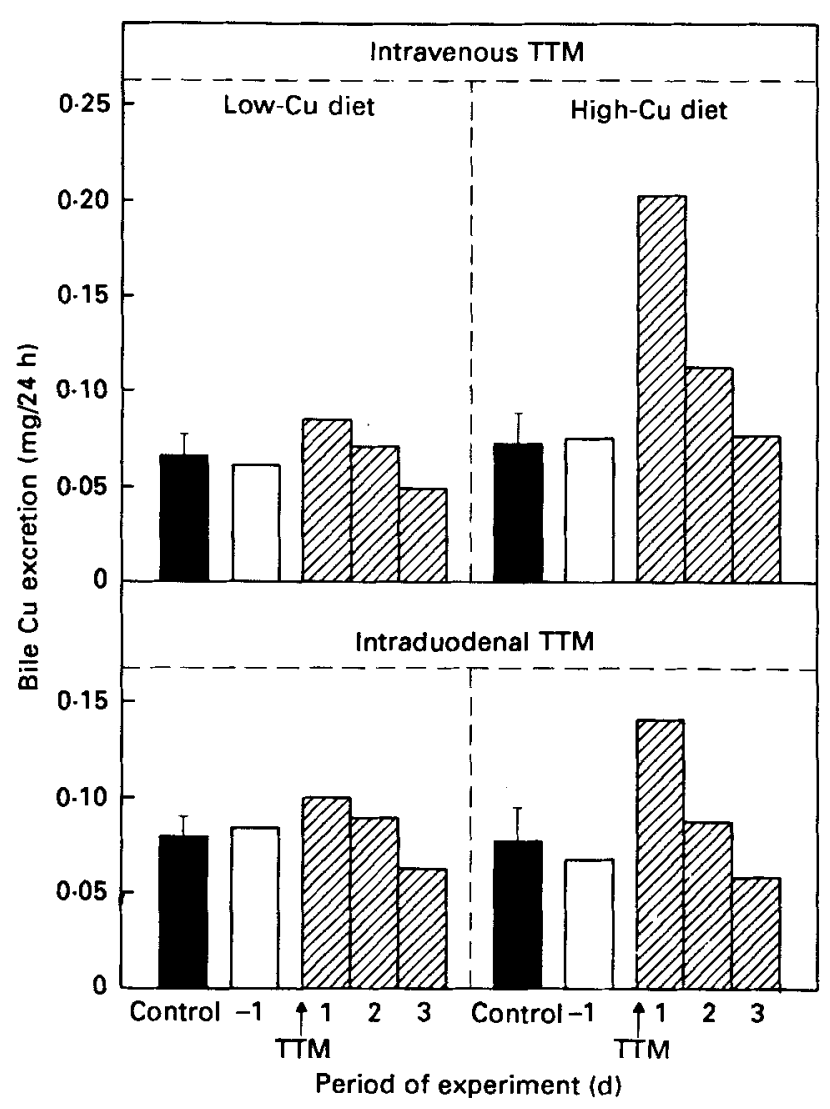

Fig. 6. Daily excretion of copper in bile before the start of the radiotracer administration (control: mean (sD represented by vertical bars) of two consecutive days sampling ( $\mathbf{C})$ ), $24 \mathrm{~h}$ before tetrathiomolybdate (TTM) administration $(-1)(\square)$, and during the $3 \mathrm{~d}$ following either intravenous or intraduodenal administration of TTM (图) in lambs fed on either a low-Cu $(5 \cdot 1 \mathrm{mg} / \mathrm{kg}$ dry matter (DM)) or a high$\mathrm{Cu}(35 \mathrm{mg} / \mathrm{kg} \mathrm{DM})$ diet.

decreased only slightly (Fig. 5) during the following $24 \mathrm{~h}$. For descriptive purposes these peaks were termed $\mathrm{A}, \mathrm{B}$ and $\mathrm{C}$. In lamb no. 3 an additional elevation of ${ }^{67} \mathrm{Cu}$ was observed at $4.5 \mathrm{~h}$. Administration of ${ }^{67} \mathrm{Cu}$ also increased stable $\mathrm{Cu}$ concentration in bile in all lambs. Elevations of stable $\mathrm{Cu}$ coincided with ${ }^{67} \mathrm{Cu}$ peaks in most instances in all but one lamb (no. 7) fed on the high- $\mathrm{Cu}$ diet. In this animal a slight increase in stable $\mathrm{Cu}$ concentration was observed between peaks $A$ and $B$ and a marked increase was observed under peak $C$. There were only minor fluctuations of ${ }^{67} \mathrm{Cu}$ and stable $\mathrm{Cu}$ concentrations during the $24 \mathrm{~h}$ before TTM administration.

Challenge with ${ }^{99} \mathrm{Mo}$-labelled TTM iv produced an immediate increase in ${ }^{67} \mathrm{Cu},{ }^{99} \mathrm{Mo}$ and stable $\mathrm{Cu}$ concentration in bile (Fig. 4). The profiles of these variables along with Mo concentration in bile were similar in pattern and frequency to those observed during the initial $24 \mathrm{~h}$ following ${ }^{67} \mathrm{Cu}$ administration and have been termed $\mathrm{A}^{1}, \mathrm{~B}^{1}$ and $\mathrm{C}^{\mathbf{1}}$. But an important finding in this experiment was the absence of the $\mathrm{B}^{1}$ peak of ${ }^{67} \mathrm{Cu}$ in bile from three lambs. In lamb no. 8 given TTM id, two $B^{1}$ peaks $\left(B_{1}^{1}\right.$ and $\left.B_{2}^{1}\right)$ for ${ }^{99} \mathrm{Mo}$ and stable $C u$ concentration were observed (Fig. 5). However, only a slight elevation of ${ }^{67} \mathrm{Cu}$ occurred at approximately $2 \mathrm{~h}$ and this did not coincide with either of the $B_{1}^{1}$ or the $B_{2}^{1}$ peaks. In all lambs the levels of ${ }^{67} \mathrm{Cu},{ }^{99} \mathrm{Mo}, \mathrm{Cu}$ and $\mathrm{Mo}$ were most marked in peak $\mathrm{C}^{1}$. In lamb no. 8 , 


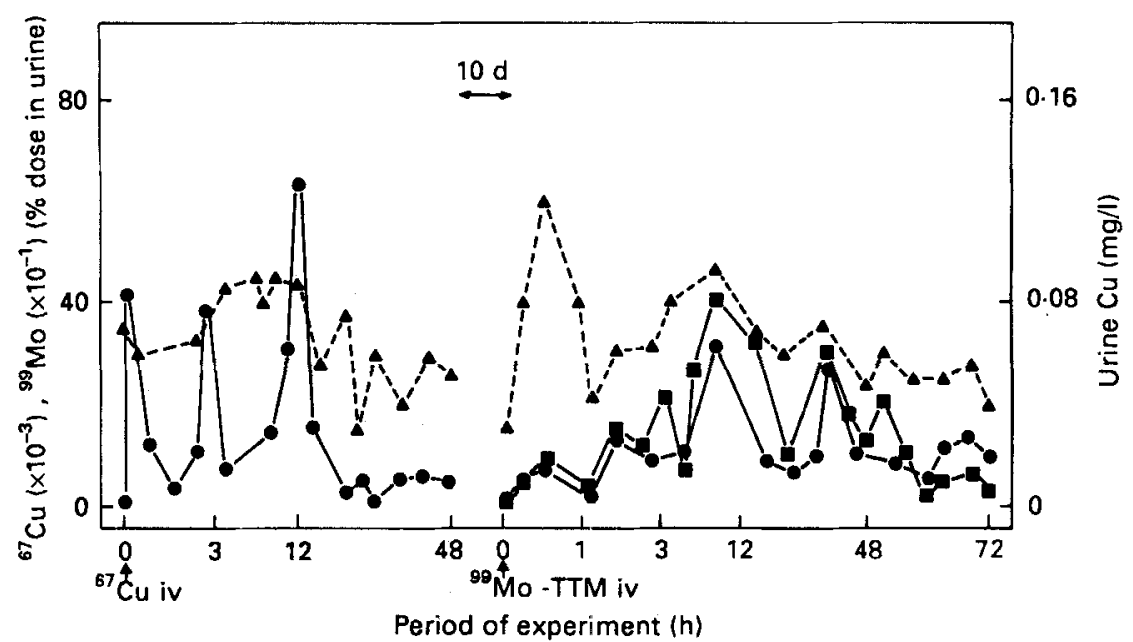

Fig. 7. Changes in ${ }^{67} \mathrm{Cu}(-\longrightarrow),{ }^{99} \mathrm{Mo}(\boldsymbol{\square}-\mathbf{C})$ and $\mathrm{Cu}\left(\boldsymbol{A}_{---}\right)$concentrations in urine of lamb no. 7 infused intravenously (iv) with ${ }^{67} \mathrm{Cu}(1.5 \mathrm{mCi} ; 0.6 \mathrm{mg} \mathrm{Cu})$ and challenged $10 \mathrm{~d}$ later with ${ }^{99} \mathrm{Mo}-$ labelled tetrathiomolybdate $\left({ }^{99} \mathrm{Mo}-\mathrm{TTM} ; 0.2 \mathrm{mCi}, 5.9 \mathrm{mg} \mathrm{Mo}\right)$ infused iv.

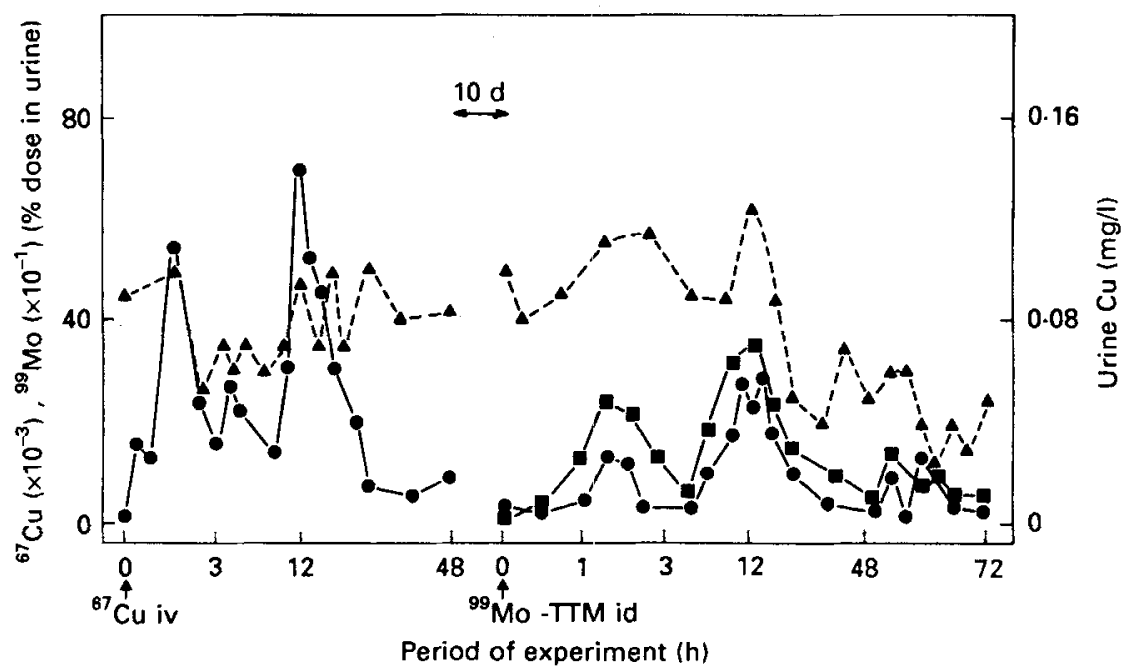

Fig. 8. Changes in ${ }^{67} \mathrm{Cu}(-\longrightarrow),{ }^{99} \mathrm{Mo}(\mathbf{C}-\mathbf{C})$ and $\mathrm{Cu}(\mathbf{A}---\mathbf{A})$ concentrations in urine of lamb no. 8 infused intravenously (iv) with ${ }^{67} \mathrm{Cu}(1.5 \mathrm{mCi} ; 0.6 \mathrm{mg} \mathrm{Cu})$ and challenged $10 \mathrm{~d}$ later with ${ }^{98} \mathrm{Mo}-$ labelled tetrathiomolybdate ( ${ }^{98} \mathrm{Mo}-\mathrm{TTM} ; 0.3 \mathrm{mCi}, 8.85 \mathrm{mg} \mathrm{Mo}$ ) infused intraduodenally (id).

two additional peaks of ${ }^{67} \mathrm{Cu}$ not accompanied by either stable $\mathrm{Cu}$ or ${ }^{99} \mathrm{Mo}$ were observed.

Administration of TTM was effective in increasing the bile $\mathrm{Cu}$ concentration and this was most marked in lambs fed on the high-Cu diet (Fig. 6). Bile Cu excretion expressed as the percentage increase over the $24 \mathrm{~h}$ period before TTM administration was most marked in lambs given TTM iv. In all lambs the greatest increase in bile $\mathrm{Cu}$ was observed during the initial $24 \mathrm{~h}$ following TTM administration. Thereafter the $\mathrm{Cu}$ concentration declined to pre-TTM levels or lower by day 3 . 


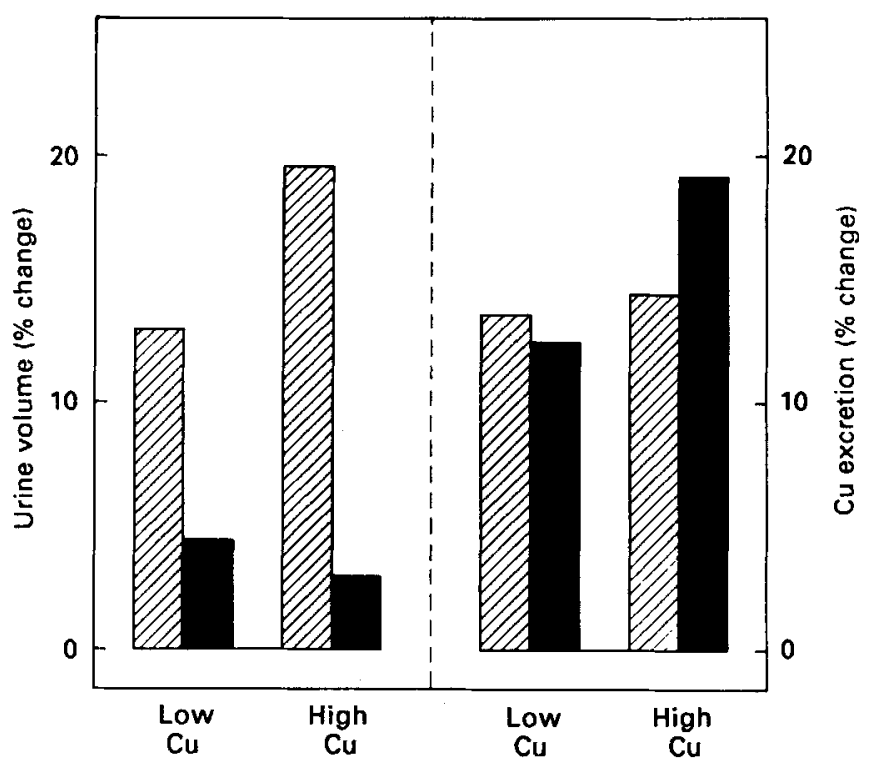

Fig. 9. The effect of administration of tetrathiomolybdate (TTM) either intravenously (iv) (蟌) or intraduodenally (id) ( $\square$ ) on changes in the volume of urine and excretion of copper in urine within a 24 $\mathrm{h}$ period for lambs given low-Cu $(5.1 \mathrm{mg} / \mathrm{kg}$ dry matter $(\mathrm{DM}))$ or high-Cu $(35 \mathrm{mg} / \mathrm{kg} \mathrm{DM})$ diets. The values are expressed as the percentage change from values for the $24 \mathrm{~h}$ period before TTM administration.

\section{Excretion of ${ }^{67} \mathrm{Cu},{ }^{99} \mathrm{Mo}$ and stable $\mathrm{Cu}$ in urine}

Radioactivity appeared quickly in urine after ${ }^{67} \mathrm{Cu}$ administration (Figs. 7 and 8). Levels of ${ }^{67} \mathrm{Cu}$ fluctuated during the $48 \mathrm{~h}$ period following ${ }^{67} \mathrm{Cu}$ administration. These fluctuations were most marked during the initial $12 \mathrm{~h}$ when two to three peaks were present. In all lambs except one (no. 7), stable $\mathrm{Cu}$ concentration in urine increased immediately following ${ }^{67} \mathrm{Cu}$ administration. In lamb no. 7 (Fig. 7) stable $\mathrm{Cu}$ concentration in urine initially declined but began increasing after $30 \mathrm{~min}$. In all lambs the fluctuations of stable $\mathrm{Cu}$ concentrations in urine coincided in most instances with changes in ${ }^{67} \mathrm{Cu}$. Samples taken during the $24 \mathrm{~h}$ period before TTM administration showed only minor fluctuations of urine ${ }^{67} \mathrm{Cu}$ and stable $\mathrm{Cu}$ concentrations, which had stabilized to $<0.5 \times 10^{-3} \%$ of the injected dose and $<0.042 \mathrm{mg} / 1$ respectively. TTM administration (iv) immediately increased urine ${ }^{67} \mathrm{Cu}$, ${ }^{99} \mathrm{Mo}$ and stable $\mathrm{Cu}$ excretion (Fig. 7). Injection of TTM id (lamb no. 8) resulted in a gradual increase in ${ }^{67} \mathrm{Cu},{ }^{99} \mathrm{Mo}$ and stable $\mathrm{Cu}$ concentration after a $10 \mathrm{~min}$ lag period (Fig. 8). Such a lag period was not apparent in lamb no. 4, which also received TTM id but was fed on a low- $\mathrm{Cu}$ diet. A series of peaks of ${ }^{67} \mathrm{Cu},{ }^{99} \mathrm{Mo}$ and stable $\mathrm{Cu}$ concentration in urine of different amplitudes occurred in all animals thoughout the $72 \mathrm{~h}$ post-TTM sampling period. In all lambs TTM administration resulted in moderate increases in urine volume and in marked increases in urine $\mathrm{Cu}$ excretion (Fig. 9). This was most marked in lamb no. 7 fed on the high- $\mathrm{Cu}$ diet and given TTM iv.

\section{Faecal Cu excretion}

Faecal $\mathrm{Cu}$ excretion increased in all animals after TTM. The percentage increase in average daily excretion of faecal $\mathrm{Cu}$ over the $72 \mathrm{~h}$ period after TTM administration compared with the $24 \mathrm{~h}$ period before TTM was $2 \cdot 2,1 \cdot 0$ and $7 \cdot 6 \%$ for lamb nos. 3,7 and 8 respectively. The results for lamb no. 4 are not available. 


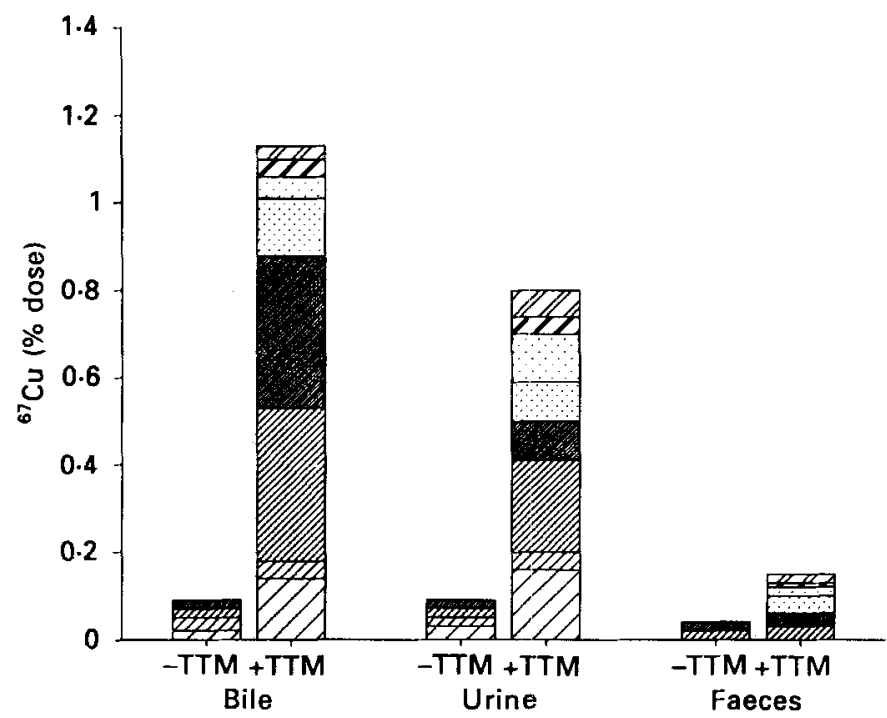

Fig. 10. Comparison of the cumulative excretion of ${ }^{67} \mathrm{Cu}$ in bile, urine and faeces from lamb no. 7, 24 $\mathrm{h}$ before and $72 \mathrm{~h}$ after challenge with intravenous ${ }^{99} \mathrm{Mo}$-labelled tetrathiomolybdate (TTM; $0.2 \mathrm{mCi}, 5.9$

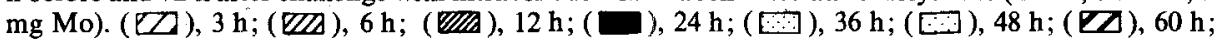
(ZD), $72 \mathrm{~h}$.

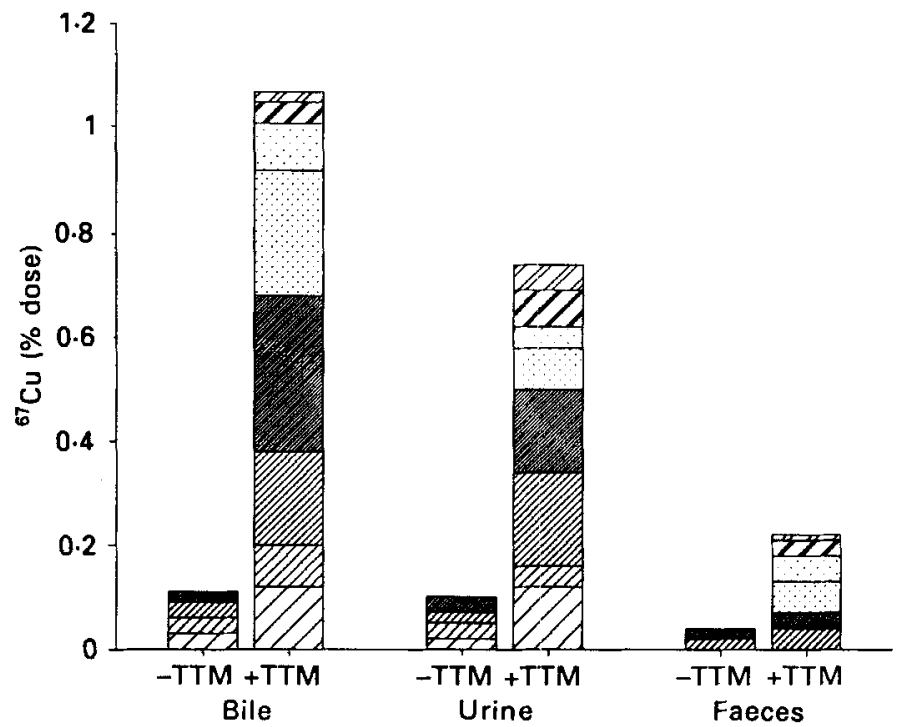

Fig. 11. Comparison of the cumulative excretion of ${ }^{67} \mathrm{Cu}$ in bile, urine and faeces from lamb no. 8,24 $\mathrm{h}$ before and $72 \mathrm{~h}$ after challenge with intraduodenal ${ }^{99} \mathrm{Mo}$-labelled tetrathiomolybdate (TTM; $0.3 \mathrm{mCi}$,

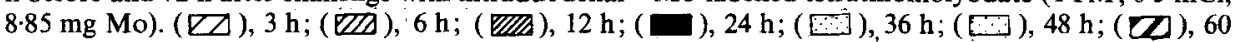
h; $(\mathbb{Z Z}), 72 \mathrm{~h}$.

Cumulative excretion of ${ }^{67} \mathrm{Cu}$ and ${ }^{99} \mathrm{Mo}$ in bile, urine and faeces Administration of TTM increased ${ }^{67} \mathrm{Cu}$ excretion via all the major excretory pathways: bile, urine and faeces. Cumulative excretion of ${ }^{67} \mathrm{Cu}$ was similar in the two animals given TTM iv (Fig. 10) or id (Fig. 11). Excretion of ${ }^{67} \mathrm{Cu}$ was highest in bile $>$ urine $>$ faeces. 


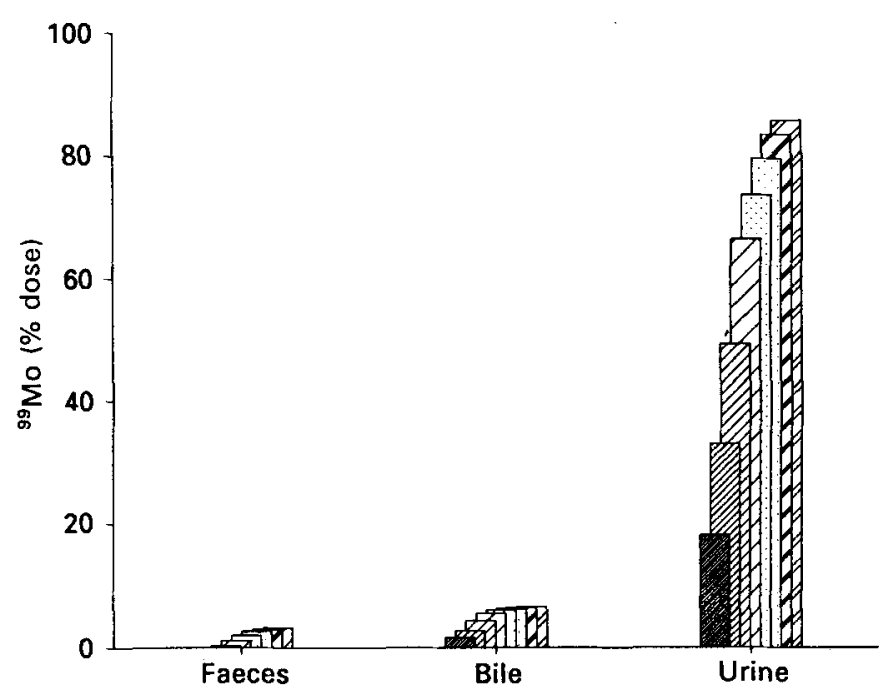

Fig. 12. Cumulative excretion of ${ }^{99} \mathrm{Mo}$ in bile, urine and faeces from lamb no. 7 primed intravenously with ${ }^{67} \mathrm{Cu}(1.5 \mathrm{mC} ; 0.6 \mathrm{mg} \mathrm{Cu})$ and challenged intravenously with ${ }^{90} \mathrm{Mo}$-labelled tetrathiomolybdate

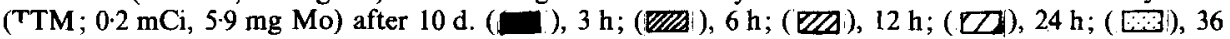
$\mathrm{h} ;([\because]), 48 \mathrm{~h} ;\left(\square_{1}\right), 60 \mathrm{~h} ;(\square \nexists), 72 \mathrm{~h}$.

Excretion of ${ }^{67} \mathrm{Cu}$ was higher in faeces in lambs given TTM id (Fig. 11) than in those given TTM iv.

Treatment with TTM iv resulted in the recovery of most of the ${ }^{99} \mathrm{Mo}$ in urine (Fig. 12) and less than $11 \%$ was excreted in both bile and faeces over the $72 \mathrm{~h}$ period. In contrast, TTM id resulted in the recovery of $34-38 \%$ of the injected dose in the faeces, $27-35 \%$ in the urine and less than $5 \%$ in bile.

\section{DISCUSSION}

The results demonstrate that TTM is not only capable of removing recently stored tissue $\mathrm{Cu}$ (Gooneratne et al. 1989), but that it also efficiently removes $\mathrm{Cu}$ from long-term tissue $\mathrm{Cu}$ storage compartments. The liver plays a central role in $\mathrm{Cu}$ metabolism. Therefore it is reasonable to suggest that the systemic, bile and urine $\mathrm{Cu}$ changes occurred through the action of TTM on liver. To accommodate the present findings we have modified and extended the three-compartment model for liver $\mathrm{Cu}$ metabolism by Weber et al. (1983; Fig. 13). The removal of $\mathrm{Cu}$ from liver by TTM is accomplished in two ways. First, liver $\mathrm{Cu}$ is returned to the blood compartment resulting in increased blood $\mathrm{Cu}$. This probably accounts for the increased $\mathrm{Cu}$ excretion in urine and faeces and for a small percentage of the increase in bile $\mathrm{Cu}$ excretion. Second, the excretion of liver $\mathrm{Cu}$ through bile is increased.

The challenge with TTM $10 \mathrm{~d}$ after injection of ${ }^{67} \mathrm{Cu}$ resulted in a more pronounced increase in stable $\mathrm{Cu}$ than in ${ }^{67} \mathrm{Cu}$ in blood, bile and urine. In a previous study (Gooneratne et al. 1989) where lambs were challenged with TTM $27 \mathrm{~h}$ after a similar injection of ${ }^{67} \mathrm{Cu}$, profiles of ${ }^{67} \mathrm{Cu}$ in blood, bile and urine were of higher amplitude. These findings suggest that TTM predominantly affects the short-term $\mathrm{Cu}$ storage compartment in the liver, although effects on long-term storage are also evident. The low level of cumulative biliary excretion of ${ }^{67} \mathrm{Cu}$ in sheep given TTM, either iv or id, emphasizes the limited effect of TTM on $\mathrm{Cu}$ removal from the long-term storage $\mathrm{Cu}$ compartment compared with its marked 


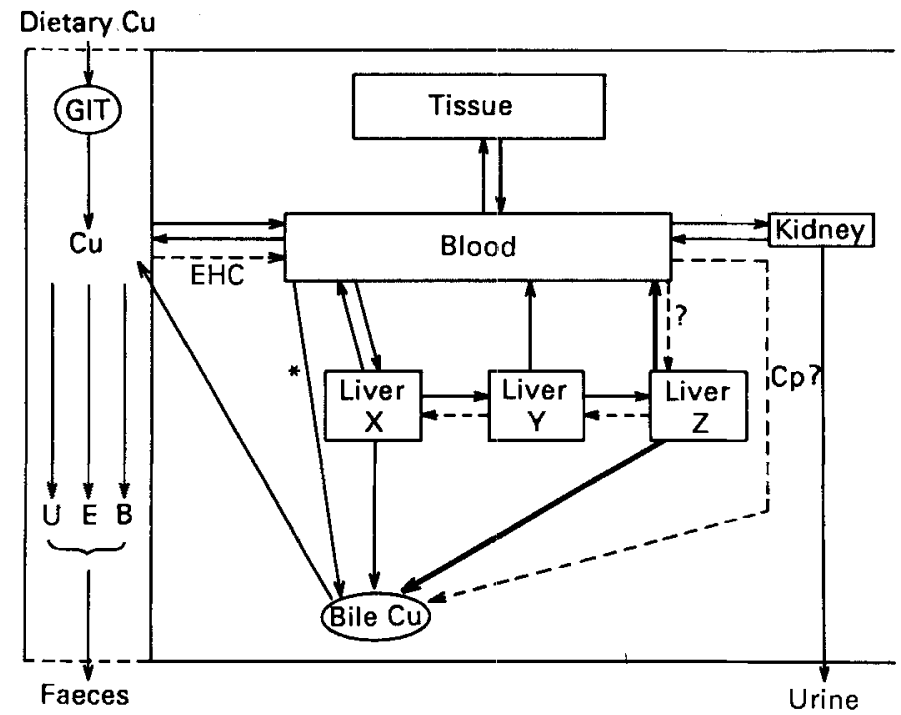

Fig. 13. Schematic diagram representing the possible movements of ingested copper in sheep given thiomolybdates (to simulate excess molybdenum and sulphur in the diet). The multifunctional role of liver in $\mathrm{Cu}$ metabolism is shown by: $\mathrm{X}$, temporary $\mathrm{Cu}$ storage compartment destined for exchange with blood $\mathrm{Cu}$ and excretion into bile; $\mathrm{Y}$, temporary storage $\mathrm{Cu}$ compartment for incorporation into caeruloplasmin $(\mathrm{Cp}) ; Z$, long-term $\mathrm{Cu}$ storage compartment which is also capable of secretion of $\mathrm{Cu}$ into blood and excretion of $\mathrm{Cu}$ into bile. $\mathrm{U}, \mathrm{E}$ and $\mathrm{B}$ are unabsorbed $\mathrm{Cu}$, endogenous $\mathrm{Cu}$ excretion and unabsorbed bile Cu respectively. * Transbiliary route of $\mathrm{Cu}$ excretion; EHC, enterohepatic circulation; GIT, gastrointestinal tract. $\rightarrow$ Removal of $\mathrm{Cu}$ from long-term storage $\mathrm{Cu}$ compartment to bile and blood (unknown pool 0 as referred to by Weber et al. 1983), which become active exclusively following TTM administration.

effects on stable $\mathrm{Cu}$ excretion in bile. Faecal ${ }^{67} \mathrm{Cu}$ excretion was most marked in lambs given TTM id (Fig. 11).

The short- and long-term liver $\mathrm{Cu}$ storage compartments are poorly defined. Subcellular $\mathrm{Cu}$ distribution (Gooneratne et al. 1979), electron microscopy (Gooneratne et al. 1980) and $\mathrm{X}$-ray microanalysis (Jones et al. 1984) studies in normal and Cu-loaded sheep suggest that primary lysosomes capture recently absorbed $\mathrm{Cu}$, and then later become secondary (dense bodies) and tertiary lysosomes (phagolysosomes) during $\mathrm{Cu}$ storage (Gooneratne et al. 1980). The latter are capable of retaining $\mathrm{Cu}$ for long periods of time (Barka et al. 1964; Goldfisher \& Sternlieb, 1968; Lindquist, 1968; Sternlieb, 1972, 1980). Hence the hepatocyte secondary and tertiary lysosomes probably constitute a majority of the liver's short-term and long-term $\mathrm{Cu}$ storage compartments respectively.

The increases in stable $\mathrm{Cu}$ concentration in plasma, bile and urine due to TTM presented here are lower than those reported when TTM challenge was performed $27 \mathrm{~h}$ after ${ }^{67} \mathrm{Cu}$ injection (Gooneratne et al. 1989). Although the lambs in the present study received the same dosage of stable $\mathrm{Cu}(0.6 \mathrm{mg})$ at the time of ${ }^{67} \mathrm{Cu}$ injection, the effects of challenge with TTM $10 \mathrm{~d}$ later on stable $\mathrm{Cu}$ excretion may have been minimal since a high percentage of this $\mathrm{Cu}$ would have been either utilized or excreted by this time. TTM was effective in removing ${ }^{67} \mathrm{Cu}$ from the long-term storage compartment in liver. However, this effect was much less pronounced (approximately $1 \cdot 71-2 \cdot 18 \%$ of ${ }^{87} \mathrm{Cu}$ injected was removed in $72 \mathrm{~h}$ from long-term $\mathrm{Cu}$ stores) compared with the effect of TTM on recently stored ${ }^{67} \mathrm{Cu}$ (approximately 7.93-9.04\% of ${ }^{67} \mathrm{Cu}$ injected was removed in $72 \mathrm{~h}$ ) (Gooneratne et al. 1989). Thus TTM appears to be 4-5 times more effective in removing $\mathrm{Cu}$ from the short-term 
storage compartment(s) than from long-term storage compartment(s). The lower effectiveness of TTM treatment after repeated injections (Gooneratne et al. 1981 b) therefore, is most likely due to a progressive depletion of the short-term $\mathrm{Cu}$ storage compartment. But the effect of TTM on excretion of $\mathrm{Cu}$ from the long-term storage compartment is still substantial, and hence may still be of clinical importance in the longterm therapy of patients suffering from Wilson's disease (Walshe, 1984) and in treatment of $\mathrm{Cu}$ toxicosis in sheep (Gooneratne et al. 1981 b). However, in view of the known toxic effect of TTM on the bone marrow (Walshe, 1986), the skeleton (Read et al. 1986) and the immature gut epithelium (Fell et al. 1979), it is not recommended for use in the young.

The possible mechanisms of excretion of recently stored liver $\mathrm{Cu}$ through bile were discussed previously (Gooneratne et al. 1989). We suggested that at least three major pathways may be involved in the transfer of $\mathrm{Cu}$ from liver to bile: (1) transbiliary, (2) transhepatocellular, and (3) hepatolysosomal. Furthermore, similar pathways were engaged in the removal of ${ }^{67} \mathrm{Cu}$ from the short-term storage compartment after administration of either ${ }^{67} \mathrm{Cu}$ or TTM. A similar profile of excretion of stable $\mathrm{Cu}$ into bile was observed in the present study which confirms the previously described observations. However, the profile of ${ }^{67} \mathrm{Cu}$ excretion in bile after TTM administration was different which suggests that a change in the pathways had occurred. In three of four animals, ${ }^{67} \mathrm{Cu}$ in peak $\mathbf{B}^{1}$ was absent. In the other lamb (no. 8) only a slight elevation was evident which was out of sequence with the ${ }^{99} \mathrm{Mo}$ and stable $\mathrm{Cu}$ concentration profiles. This suggests that only the transbiliary and hepatolysosomal pathways were operative. Thus peak $\mathbf{B}^{1}$, the transhepatocellular pathway, which we hypothesized to constitute $\mathrm{Cu}$ bound to albumin, appeared inoperative during removal of $\mathrm{Cu}$ from the long-term liver $\mathrm{Cu}$ storage compartment. The reason for this is not clear. It is not known in what form $\mathrm{Cu}$ is released from the long-term $\mathrm{Cu}$ storage compartment. This $\mathrm{Cu}$ may have a low affinity for albumin, or may bind to TTM readily in preference to albumin. The ${ }^{67} \mathrm{Cu}-\mathrm{TTM}$ would then be cleared rapidly from the bloodstream via the urine and via the transbiliary $\left(A^{1}\right)$ route of bile $\mathrm{Cu}$ excretion, or it could re-enter the liver. The large pool of serum albumin potentially acts as a buffer to increased metal levels (Woods \& Mason, 1987) and also protects TM compounds against hydrolysis (Hynes et al. 1984). In addition bovine serum albumin contains a distinct single binding site for TM of which the affinity is increased by the presence of $\mathrm{Cu}$. In the present study ${ }^{99} \mathrm{Mo}$-labelled TTM and stable $\mathrm{Cu}$ were probably bound to albumin, as evidenced by the increase of both in peak $\mathrm{B}^{1}$, while ${ }^{67} \mathrm{Cu}$ was absent. It is not known whether the forms of $\mathrm{Cu}$ which exist in the short- and long-term storage compartments differ. However, the relative abundance in plasma or a potentially greater affinity of stable $\mathrm{Cu}$ released from short-term storage may have precluded binding of ${ }^{67} \mathrm{Cu}$ from long-term storage to albumin. As reported previously (Gooneratne et al. 1989), the timing of the release of ${ }^{67} \mathrm{Cu}$ in peaks $\mathrm{C}$ and $\mathrm{C}^{1}$ indicates that it is derived from lysosomes. This may be either from secondary lysosomes (dense bodies formed after incorporation of recently stored liver $\mathrm{Cu}$ ) or tertiary lysosomes (phagolysosomes) which appear to be actively involved in long-term accumulation of $\mathrm{Cu}$ (Barka et al. 1964; Goldfischer \& Sternlieb, 1968; Lindquist, 1968; Sternlieb, 1972, 1980). The large amount of $\mathrm{Cu}$ excreted via peak $\mathrm{C}^{1}$ is in agreement with previous findings on massive liver lysosomal $\mathrm{Cu}$ storage in Wilson's disease, canine $\mathrm{Cu}$ toxicosis (Sternlieb, 1980) and in chronic $\mathrm{Cu}$ poisoning in sheep (Gooneratne et al. 1980). Collectively, these results demonstrate that in treatment and management of $\mathrm{Cu}$ toxicity in sheep, although iv TTM administration is of major significance in chelation of elevated blood $\mathrm{Cu}$ (Gooneratne et al. 1981b) and removal of recently stored $\mathrm{Cu}$ (Gooneratne et al. 1989), increases in dietary Mo and S levels may also be useful for enhancing endogenous $\mathrm{Cu}$ excretion. 
The authors thank Mr T. Berryere for care of the animals and for technical assistance. This work was supported by the Saskatchewan Agriculture Development Fund and by the Burford Hooke Hantelman Trust Fund.

\section{REFERENCES}

Barka, T., Scheuer, P. J., Schaffner, F. \& Popper, H. (1964). Structural changes of liver cells in copper intoxication. Archives of Pathology 78, 331-349.

Dick, A. T., Dewey, D. W. \& Gawthorne, J. M. (1975). Thiomolybdates and the copper--molybdenum-sulphur interaction in ruminant nutrition. Journal of Agricultural Science, Cambridge 85, 567-580.

Fell, B. F., Dinsdale, D. \& El-Gallad, T. T. (1979). Gut pathology of rats dosed with tetrathiomolybdate. Joumal of Comparative Pathology 89, 495-514.

Goldfischer, S. \& Sternlieb, I. (1968). Changes in the distribution of hepatic copper in relation to the progression of Wilson's disease (hepatolenticular degeneration). American Journal of Pathology 53, 883-901.

Gooneratne, S. R. (1986). Potential use of tetrathiomolybdate in copper storage diseases. Acta Pharmacologica et Toxicologica 59, Suppl. VII, 518-523.

Gooneratne, S. R., Chaplin, R. K., Trent, A. M., \& Christensen, D. A. (1988). Effect of tetrathiomolybdate administration on the excretion of copper, zinc, iron and molybdenum in sheep bile. British Veterinary Journal (In the Press.)

Gooneratne, S. R., Howell, J. McC. \& Cook, R. D. (1980). An ultrastructural and morphometric study of the liver of normal and copper-poisoned sheep. American Journal of Pathology 99, 429450.

Gooneratne, S. R., Howell, J. McC. \& Gawthorne, J. M. (1979). Intracellular distribution of copper in the liver of normal and copper loaded sheep. Research in Veterinary Science 16, 57-64.

Gooneratne, S. R., Howell, J. McC. \& Gawthorne, J. M. (1981 a). An investigation of the effects of thiomolybdate on copper metabolism in chronic Cu-poisoned sheep. British Journal of Nutrition 46, 469-480.

Gooneratne, S. R., Howell, J. McC. \& Gawthorne, J. M. (1981 b). Intravenous administration of thiomolybdate for the treatment and prevention of chronic copper poisoning in sheep. British Journal of Nutrition 46, 457-468.

Gooneratne, S. R., Laarveld, B., Chaplin, R. K. \& Christensen, D. A. (1989). Profiles of ${ }^{87} \mathrm{Cu}$ in blood, bile, urine and faeces from ${ }^{67} \mathrm{Cu}$-primed lambs: effect of ${ }^{99} \mathrm{Mo}$-labelled tetrathiomolybdate on the metabolism of recently stored tissue ${ }^{67} \mathrm{Cu}$. British Journal of Nutrition $61,355-371$.

Hynes, M., Lamand, M., Montel, G. \& Mason, J. (1984). Some studies on the metabolism and the effects of ${ }^{98} \mathrm{Mo-}$ and ${ }^{35} \mathrm{~S}$-labelled thiomolybdates after intravenous infusion in sheep. Journal of Inorganic Biochemistry 24, $279-288$.

Jones, H. B., Gooneratne, S. R. \& Howell, J. McC. (1984). X-ray microanalysis of liver and kidney in copper loaded sheep with and without thiomolybdate administration. Research in Veterinary Science 37, $273-279$.

Lindquist, R. R. (1968). Studies on the pathogenesis of hepatolenticular degeneration. III. The effect of copper on rat liver lysosomes. American Journal of Pathology 53, 903-927.

Mason, J. (1986). Thiomolybdates: mediators of molybdenum toxicity and enzyme inhibitors. Toxicology 42 , 99-109.

Mills, C. F., Bremner, I., El-Gallad, T. T., Dalgarno, A. C. \& Young, B. W. (1978). Mechanisms of molybdenum/sulphur antagonism of copper utilization by ruminants. In Trace Element Metabolism in Man and Animals (TEMA-3), pp. 150-158 [M. Kirchgessner, editor]. Weihenstephan: Arbeitskreis für Tierernährungsforschung.

Read, R., Sutherland, J. \& Ghosh, P. (1986). The matrix components of the epiphyseal growth plate and articular cartilage from dogs treated with ammonium tetrathiomolybdate, a copper antagonist. Australian Journal of Experimental Biology and Medical Science 64, 545-562.

Sternlieb, I. (1972). Evolution of the hepatic lesion in Wilson's disease (hepatolenticular degeneration). In Progress in Liver Diseases, vol IV, pp. 511-525. [H. Popper and F. Schaffner, editors]. New York, London: Grune and Stratton.

Sternlieb, I. (1980). Copper and the liver. Gastroenterology 78, 1615-1628.

Suttle, N. F. (1980). The role of thiomolybdate in the nutritional interactions of copper, molybdenum and sulfur: fact or fantasy? Annals of the New York Academy of Science 355, 195-204.

Underwood, E. J. (1977). Trace Elements in Human and Animal Nutrition, 4th ed. New York and London: Academic Press.

Walshe, J. M. (1984). Copper: its role in the pathogenesis of liver disease. Seminars in Liver Disease 4, $252-263$.

Walshe, J. M. (1986). Tetrathiomolybdate $\left(\mathrm{MoS}_{4}\right)$ as an 'anticopper' agent in man. In Orphan Diseases/Orphan Drugs, pp. 76-85 [I. H. Scheinberg and J. M. Walshe, editors]. Manchester: Manchester University Press.

Weber, K. M., Boston, R. C. \& Leaver, D. D. (1980). A kinetic model for copper metabolism in sheep. Australian Journal of Agricultural Research 31, 773-790.

Weber, K. M., Boston, R. C. \& Leaver, D. D. (1983). The effect of molybdenum and sulphur on the kinetics of copper metabolism in sheep. Australian Journal of Agricultural Research 34, 295-306.

Woods, M. \& Mason, J. (1987). Spectral and kinetic studies on the binding of trithiomolybdate to bovine and canine serum albumin in vitro: the interaction with copper. Joumal of Inorganic Biochemistry 30, 261-273. 